\title{
The Right to Health: The Devil is in the Doing
}

Addressing the world's injustices in all forms is the only way to breathe life into the "health for all" principle and aspiration expressed so eloquently in the 1978 Alma-Ata Declaration. The first of these injustices is more evident than it was 41 years ago: the international economic order has concentrated vast wealth in everfewer pockets, while half the world's people go without essential health services ... and most certainly without the economic, social, political and cultural conditions and empowerment needed to otherwise thrive.

This massive violation of rights can only be addressed by governments acting in concert-defended and demanded by progressive civil society participation-to take responsibility for ensuring that the likes of health and education are public goods, available and accessible to all without discrimination. This is a tall order for a growing number of global leaders who seem hellbent to run in the opposite direction, unwavering in corporate commitments but unwilling to confront the alarming consequences of climate change; epidemics old and new; or gender, age, socioeconomic, racial, ethnic, religious and geographic inequities. They have contributed to the causes, not the solutions, for millions of people for whom death is simply a relief from suffering.

In this context, it is no wonder that scant attention is paid to efforts by the low- and middle-income countries to address inequities within and across borders. In fact, the attention that does go their way tends to depict one humanitarian crisis after another, and to demand that governments in Africa, Asia, Latin America and the Caribbean simply step up and do a better job with the scarce resources at hand. Such "bootstrap economics," coupled with minimal, strings-attached foreign aid, is somehow expected to make a real difference ... or perhaps not.

Lost in the global shell game of resources in any case are the innovations emerging from the Global South itself, often times necessity being the mother of invention. But undoubtedly, the different approaches and strategies some are implementing can make key contributions to solving problems of equity and equality faced by this (for better or worse) globalized world. Such is the case of Cuba, a country of 11.2 million, which took a new path 60 years ago, and now by all accounts has one of the world's healthiest and most educated populations. Whatever one's political inclinations, these facts merit further study.

Thus, as representatives of nearly 200 countries gather at the first UN High-level Meeting on Universal Health Coverage, MEDICC Review takes the opportunity to share with readers both the results and challenges of several Cuban programs and strategies that have extended the right to health in Cuba and abroad.

This issue is intended as a followup to the Pan American Journal of Public Health's 2018 special issue on Cuba's health system,[1] which painted in broad scientific strokes the evolution, practice and transformations in areas such as maternal-child health, prevention and control of communicable diseases, climate change mitigation, and human resource training; as well as challenges ranging from the economic to the demographic, including rapid population aging. Most importantly, it described and analyzed a fundamental pillar of Cuba's single, universal public health system: the strategy of primary health care, which involves health professionals with their communities in protecting and constructing health, informs other levels of care and decisionmaking, and generates greater attention to the social determinants of health.

We introduce our own special issue with another pillar undergirding Cuban public health: the political will to make health a priority, despite resource constraints. In his paper, Dr Lage-Dávila presents the paradox of impressive health outcomes achieved within limited resources, compounded by global economic vicissitudes and US economic sanctions, and illustrated in a biotechnology sector at the service of public health. He challenges new generations globally to use scientific approaches for tackling society-wide problems lest rapidly changing technologies outpace abilities to harness them for the public good, allowing profit-making to reign over social development.

While most of the articles that follow focus on Cuban public health programs and research implementation, two look at broader experiences and their relation to "leave no one behind" and critically, to "leave no one behind while moving forward." The first of these is by Dr Castell-Florit, who refers to the constitutional and legal framework in Cuba providing for the right to health, as well as health as a component of overall policymaking and the intersectoral imperative ... "health in all policies," looking ahead to "one health."

Dr Álvarez, Distinguished Member and Secretary of the Cuban Academy of Sciences, provides the perspective of an activist determined to incorporate a gender perspective into policy formulation and practice. She shares thoughts on factors affecting women's presence in Cuban and global science, and what can be done to enhance it. Cuba's Academy has the highest percentage of women of any in the world (34\% in 2018). But, as she reflects, there is much more to be done in this country where women still do 14 more hours a week of household chores than men, no matter their professional or leadership roles. This gender discussion is pertinent to health for all in the context of social goals-as Dr Álvarez quite cogently puts it: "to reap development, you must sow science," and that means liberating the full potential of women and girls.

The health of women and children is the focus of one of Cuba's national public health programs, the others devoted to older adult health, communicable diseases, chronic non-communicable diseases, and natural and traditional medicines. Four manuscripts bring the Maternal-Child Health Program into clearer focus as it relates to ensuring health for all, the most vulnerable first. Dr Rojas-Ochoa chronicles Cuba's almost six-decade experience with maternity homes for at-risk pregnant women, an institution that also represents the health system's flexibility in meeting different challenges through time. He also cautions that health equity must remain a central emphasis as the system as a whole seeks greater efficiency, advice worth heeding well beyond his own country, as trends in infant and maternal mortality are revealing indicators, especially when disaggregated.[2]

Also in the domain of maternal-child health, Dr Abreu-Suárez writes of challenges faced by Cuban efforts to eliminate childhood 
tuberculosis; and Dr Esquivel-Lauzurique describes the use of growth and development studies to follow the health of Cuban children over decades.

Finally, Dr Marcheco-Teruel recounts the principles, practice and results of Cuba's national sickle-cell anemia program, relating it to ethics, reproductive rights, and the rights and treatment of children born with this genetic condition.

The difficult process of putting science to work for the most vulnerable is reflected in two more papers in this MEDICC Review issue: Dr Rodríguez-Labrada recounts the determination of scientists to establish in Holguín, a city in eastern Cuba, a topflight institution dedicated to research and rehabilitation for rare hereditary ataxias. While no cure has been discovered for the condition, which is fatal, the center has developed considerable scientific potential and its results with patients and families are encouraging.

The experience of Cuban biotechnology in lifesaving vaccines is the focus of an article by Dr Sierra-González concerning the Finlay Institute's VA-MENGOC-BC, the world's first vaccine proven effective against serogroup $B$ meningococcal infection. Developed in response to an epidemic among youngsters that was declared Cuba's number one public health problem in the 1980 s, the vaccine was successful and was later used to combat outbreaks in other countries. It is disconcerting to recall that, despite the vaccine's existence and disposition of Cuban scientists, collaboration with US researchers in this area stalled. One wonders if such cooperation might have given a better chance to the 100 youngsters who lost their lives to serogroup B meningitis in Washington state alone (1989-2007) or to the university students stricken in other states during the 2013 outbreaks. (It was not until 2014 that another fast-tracked serogroup B vaccine was licensed in the USA.) $[3,4]$

In a related article, Dr Galindo-Santana provides a Cuban perspective on the antivaxxer movement and its now ubiquitous social media attacks on childhood vaccination. She also proposes ways to maintain public trust in vaccine safety, with a view to sustaining Cuba's high immunization coverage (>99\%). Her voice, urging health professionals to keep science front and center and engage in broad public education, is important for Cuba and other latitudes as well. WHO recently announced retraction of measlesfree status from four European countries, including the UK, where antivaxxer misinformation campaigns have caused immunization rates to plummet. In 2018, there were 991 confirmed cases in England and Wales, up from 284 in 2017, and 230 in just the first quarter of 2019.[5]

Prioritizing health and putting science to work for public health are joined in Cuba's case with a third essential element: global health cooperation. This issue carries four papers offering an inside look at the principle and Cuban practice, particularly South-South collaboration: Dr Peix relates cooperation with the International Atomic Energy Agency to assist in developing human resources and standardized protocols in nuclear cardiology throughout Latin America and the Caribbean, to ensure more equitable access to lifesaving technologies.

Dr Herrera-Valdés describes experiences in intersectoral action and South-South cooperation to tackle the epidemic of chronic kidney disease of nontraditional etiology in El Salvador, first observed among subsistence farmers in that Central American nation, but now found throughout the region and elsewhere. Scientists hypothesize that labor conditions plus agrochemicals may play roles in the disease, which has already felled 20,000 in El Salvador alone.

Dr Pérez-Ávila's article is one of the first publications describing the work of the 256 Cuban health professionals who cared for Ebola patients in West Africa during the epidemic in Liberia, Sierra Leone and Guinea. The reference is tragically relevant now, as Ebola once again threatens the lives of people in the Democratic Republic of the Congo, neighboring African countries and worldwide.

Senior Editor Gorry has written a comprehensive article that reviews six decades of Cuban global health cooperation, in which over 400,000 Cuban health professionals have served abroad, primarily in disaster zones or in marginalized communities and remote settings, providing care for the world's most vulnerable. Gorry's feature brings health for all full circle in the Cuban context, as global health cooperation and relations-whether health services, technology transfer or biotech collaboration and exports-hold the key to sustainability for Cuba's single, universal health system, with care free to patients.

The economic and demographic road ahead is undoubtedly a difficult one, and not only for Cuba. Without minimizing the value of global debates on universal health, health care or health coverage, we venture that the urgency faced by low- and middleincome countries - and by marginalized populations everywheredemands action towards greater health equity and in the form of practical, working models. In such circumstances, the advice of Cuban independence hero José Martí is as compelling now as it was over a century ago: "The best way to say . . . is to do."

In making this issue possible, we are grateful for the cooperation and support provided by PAHO/WHO's representation in Havana, The Atlantic Philanthropies, Ford Foundation and The Christopher Reynolds Foundation. -1/h-

\section{The Editors}

1. Pan American Health Organizaiton [Internet]. Washington, D.C.: Pan American Health Organization; c2019. Special Issues. Health system in Cuba; 2018 Apr [cited 2019 Aug 22]. Available from: https://www.paho.org/journal/en/special -issues/health-system-cuba. Spanish.

2. United Health Foundation. America's Health Rankings analysis of CDC WONDER Online Database, Underlying Cause of Death, Multiple Cause of Death files. Natality public-use data [Internet]. Minneapolis: United Health Foundation; 2018 [cited 2019 Sep 9]. Available from: https://www .americashealthrankings.org/

3. Soeters HM, McNamara LA, Blain AE, Whaley M, MacNeil JR, Hariri S, et al. University-based outbreaks of meningococcal disease caused by serogroup B, United States, 2013-2018. Emerg Infect Dis [Internet]. 2019 Mar [cited 2019 Sep 9];25(3):434-40. Available from: https://dx.doi.org/10.3201/eid2503 .181574

4. Fortner R. Meningitis B: Cuba's Got the Vaccine-Why Don't We? Yes! [Internet] 2007 May 15 [cited 2019 Sep 9]; [about 2 screens]. Available from: https://www.yesmagazine.org/issues/latin-america-rising/meningitis-b-cubas -got-the-vaccine2014why-dont-we

5. BBC Newss [Internet]. London: BBC News; c2019. Health. Measles: Four European nations lose eradication status; 2019 Aug 29 [cited 2019 Sep 9]; [about 2 screens]. Available from: https://www.bbc.com/news/health-49507253 